\title{
EFFECT OF USING ORANGE ON THE PHYSICO-CHEMICAL PROPERTIES OF RICOTTA CHEESE
}

\author{
AMAL I. EL- DARDIRY \\ Dairy Chemistry Department, Animal Production Research Institute, ARC, Giza, Egypt.
}

(Manuscript received 8 January 2017 )

\begin{abstract}
$\mathrm{R}$ icotta cheese was manufactured from whether sweet whey or sweet buttermilk fortified with (Citrus sinensis var. Balady) as a functional dairy food with high antioxidant activity and long shelf life. Ricotta cheese was fortified with 1,3 and $5 \%$ Citrus sinensis and stored at $5 \pm 1^{\circ} \mathrm{C}$ for 22 days. Subsequently, the resultant cheeses from different treatments were analyzed for antioxidant activity by using FRAP methods, chemical, microbiological, loss and recovery of protein \%, Cheese yield \%, amino acid content, chemical score, protein efficiency ratio (PER), biological value (BV)and sensory properties. Also, cost of production was determined. The results revealed that, Ricotta cheese supplemented with Citrus sinensis either made from sweet whey or buttermilk retained more ferric reducing antioxidant power (FRAP), pH values, cheese yield, amino acids and organoleptic properties. On the other hand, fortification with Citrus sinensis decreased the total bacterial count, mould \& yeast, titratable acidity, loss protein $\%$ and the cost of production. It was concluded that, Ricotta cheese could further carry more healthy benefits and extended the shelf life of Ricotta chesse when it was fortified with Citrus sinensis var. Balady whether made from sweet whey or buttermilk up to $5 \%$ but concerning organoleptic properties the level of $3 \%$ Citrus sinensis var. Balady of the resultant cheese made from whey or buttermilk was preferable.

Key words: Ricotta cheese, orange, fiber, sweet cheese whey, butter milk, , orange peel and pulp, functional foods, antimicrobial, antioxidant.
\end{abstract}

\section{INTRODUCTION}

Ricotta cheese is a dairy product of Italian origin, which means "recooked", it is produced by boiling acidified cheese whey. Ricotta cheese is a high moisture soft cheese. It can be produced using cheese whey or milk, or a mixture of both Pizzillo et al., (2005). Ricotta cheese is very mild and it is used in many Italian dishes.

Ricotta cheese shelf life is generally limited for few days due to the exposure of the product to the atmosphere prior to packaging. Moreover, due the high moisture level, the initial pH above 6 and the low salt content, Ricotta is very susceptible to spoilage by molds, yeasts and bacteria, substantially represented by Enterobacteriaceae Pint ado et al., (2001). 
Whey generated during the industrial production of cheese is a critical source of environmental organic contamination. The nutritional composition of the whey, specifically its protein content, which possess high nutritive quality with positive effects on human health because of the production of hypertensive peptides Lollo et al., (2012),

Whey proteins are known by their health effects. McIntosch et al., (1998) studied the anticarcinogenic effect of whey proteins against colon cancer. They returned that to the high content of sulphur amino acids in whey proteins.

Buttermilk, a byproduct of butter making released during churning of cream, is very rich in milk fat globule membrane (MFGM), and it has been used as a natural functional ingredient in many food products. The MFGM fragments have previously been shown to carry many beneficial health effects, i.e., inhibit colon cancer, suppress gastrointestinal pathogens, and may be involved in stress responses Dewettinck et al. (2008).

In addition to the high nutritional value of buttermilk that is considered as health promoting compounds, it has a high water holding capacity Turcot et al., (2001) which in turn may reduce or eliminate the whey off. Accordingly, adequate addition of buttermilk may offer a promising replacement to stabilizers in low- and fatfree yogurt production.

Citrus fruits are the leading fruit trees grown-up all over the world and are well honored for their energizing and pleasing juice and fitness pay backs. Many healing characteristics have been endorsed to citrus fruits like antiviral, antiinflammatory, anti-turmeric, anticancer and special effects on capillary in stability in addition to capability to prevent aggregation of platelets. In recently times, curative advantages in relation to heart diseases and muscular deterioration in relation to age have been reported. Citrus fruits have abundant health benefits that are related to the increased values of bioactive compounds and phytochemical such as phenols, flavonoids, carotenoids, vitamins and minerals obtainable in citrus fruits. These nutrients stimulate the immune systems and may act as antioxidants. In citrus species phytonutrients and vitamins may be the reason for the antioxidant property Fernandez-Lopez et al., (2005).

Approximately $50 \%$ of the orange fruit is juice, while other $50 \%$ is the rind, albedo, sacs and seeds, which contain varying amount of water, soluble sugars, fiber, organic acids, amino acids, proteins, minerals, oils and lipids, and also contains flavonoids and vitamins. All of these components are found in different amounts depending on the fraction of the fruit (juice, albedo, flavedo, rag, pulp, and seeds) 
and therefore, their proportion in citrus juice residues depends on the juice extraction system use Saénz et al., (2007).

Therefore, this work was carried out to study the effect of using orange juice, peel and pulp on the composition and quality of Ricotta cheese. Also, using the buttermilk in making Ricotta cheese and its comparison with using sweet whey. The preparation of Ricotta cheese is an economic way to use this by products as getting rid of the pollution of the environment, also, their high nutritional value which considered one of the most cost-effective products that use cheese whey or buttermilk plus juice, pulp and peel orange.

So, the aim of this studyis manufacturing new type flavored Ricotta cheese fortified with orange fruit such to: improve the functional and sensory properties of Ricotta cheese, prolonged the shelf life, nutritional values and improving biological values.

\section{MATERIALS AND METHODS}

\section{Materials:}

Mozzarella cheese sweet whey was obtained from the dairy factory in faculty of agriculture, Cairo University, Giza, Egypt. Sweet buffalo buttermilk (0.65\% fat) was obtained from the Dairy Unit, Animal production Research Institute, Egypt. Commercial fine grade salt was obtained from El-Nasr Salines Company, Alexandria, Egypt. Citric acid was obtained from Piochem, Co., Egypt. Mature orange fruits (Citrus sinensis var. Balady) was purchased from the local market. Table 1, shows the chemical composition of sweet whey, buttermilk, orange juice and dried orange peel+pulp. used in the present study.

Table 1 . The chemical composition of sweet whey, buttermilk, orange juice and dried orange peel+pulp.

\begin{tabular}{|c|c|c|c|c|}
\hline Component & Sweet whey & $\begin{array}{c}\text { Sweet } \\
\text { buttermilk }\end{array}$ & Orange juice & $\begin{array}{c}\text { Orange pell + } \\
\text { pulp powder }\end{array}$ \\
\hline Total Solids \% & 6.79 & 9.55 & 12.13 & 94.67 \\
\hline Protein \% & 0.92 & 3.54 & 0.81 & 8.49 \\
\hline Ash \% & 0.61 & 0.72 & 0.48 & 13.11 \\
\hline Fat \% & 0.48 & 0.65 & - & 2.26 \\
\hline Total dietary fiber \% & - & - & 0.028 & 60.21 \\
\hline $\begin{array}{c}\text { Available } \\
\text { Carbohydrates \% }\end{array}$ & 4.78 & 4.64 & & 10.6 \\
\hline Titratable acidity \% & 0.32 & 0.14 & 1.02 & 0.69 \\
\hline pH- value & 5.7 & 6.71 & 3.72 & 5.01 \\
\hline $\begin{array}{c}\text { Caratenoids, } \\
\text { (mg/100g ) }\end{array}$ & - & - & 2.38 & 54.34 \\
\hline Flavonoid mg/g & - & - & 4.21 & 27.32 \\
\hline Pectin mg/g & - & - & - & 35.24 \\
\hline
\end{tabular}




\section{Experimental procedures:}

\section{Preparation of orange dietary fibers}

Orange fibers (peel+ pulp) were prepared according to Fernandez-Lopez, et al., (2004).

The resultant fibers were grounded and screened to obtain powder product (particle size of less than $0.417 \mathrm{~mm}$ ).

\section{Preparation of orange juice}

Orange fruit was carefully washed by tap water and dried by air at room temperature. Orange juice was obtained by cutting the fruits with knife into halves, manually squeezed using laboratory juice extractor and then filtered through cheese cloth.

\section{ManufacturingRicotta cheese fortified with orange}

Different Ricotta cheeses fortified with different level of Citrus sinensis manufactured using the traditional method as described by Mahran et. al., (1999), with some modificationas follow:

Mozzarella cheese whey was placed in cheese vat and neutralized to acidity $0.13 \%$ as lactic acid by addition of food grade sodium hydroxide solution. The mix was divided to four portions. The first portion was used for manufacture of control Ricotta cheese made without any additives. The second portion was added $1 \%$ Citrus sinensis, the third portion was added $3 \%$ Citrus sinensis. Finally portion was added $5 \%$ Citrus sinensis. All mixtures were heated to $65^{\circ} \mathrm{C}$ to destroy residual rennet which would cause premature coagulation of casein. All the mixtures were heated to 88$90^{\circ} \mathrm{C}$ for $15 \mathrm{~min}$. acidulate (10\% citric acid) and $0.5 \% \mathrm{NaCl}$ for control but other mixtures acidulate (orange juice to reach $\mathrm{pH} 5.9-6.0$ ) and $0.5 \% \mathrm{NaCl}$. The curd was left in the mixture whey for 20 min before draining. Traditionally the curd is ladled from surface of the whey. This was found to be cumbersome and it was more convenient to run off the whey. Fines were removed from the curd using a muslin filter. After draining the curd was packaged into plastic containers (100 gm) and stored at $5 \pm 1^{\circ} \mathrm{C}$ for 22 days.

The same system in manufacture was applied by replacement of the Mozzarella cheese whey with sweet buttermilk.

\section{Analytical methods}

Dry matter, fat, ash, titratable acidity (TA\%) and total protein (TP) contents were determined in both raw materials and cheese samples according to the method described by AOAC (2012). The pH values were measured using Lab. pH meter with a combined electrode, Hanna digital $\mathrm{pH}$ meter. Fiber content of raw materials and 
different Ricotta cheese samples was determined as described by AOAC (2012). The loss of protein in different treatments was calculated using the following equation:

$$
\text { Protein loss } \%=\frac{\% \text { Protein in filtrate residual }}{\% \text { protein in in mixture materials }} \times 100
$$

Recovery of protein content in different Ricotta cheese samples was calculated as follow:

$$
\text { Recovery of proteins } \%=100-\text { protein Loss } \%
$$

The yield of cheese is a mathematical expression for the quantity of cheese obtained from given quantity of raw materials as the formula given by Fox et al., (2000).

$$
\text { Cheese yield } \%=\frac{\text { Amount of cheese }(\mathrm{kg})}{\text { Amount of original raw material }(\mathrm{kg})} \times 100
$$

Carbohydrate content of all samples was calculated as described by Ceirwyn, (1995) using the following formula:

$\%$ Carbohydrates = $100-$ ( $\%$ fat+\%protein+\% ash+\%fiber $+\%$ moisture $)$.

The amino acids contents were determined by high performance amino acids analyzer according to the method described by AOAC (2012).

\section{Biological evaluation:}

Protein efficiency ration (PER) was estimated by using equation reported by (Alsmeyer et al., 1974).

$$
\text { PER }=0.684+0.456 \text { (Leucine) }-0.647 \text { (Proline) }
$$

Biological value (BV) was estimated using the equation reported by Mitchel and Block, (1946).

$$
\mathrm{BV}=49.9+10.53 \text { PER. }
$$

\section{Amino acids score (AAS):}

Amino acids score (AAS) was calculated by using the FAO/ WHO scoring pattern (1973), as follows:

$$
\text { AAS } \%=\frac{\mathrm{mg} \text { of amino acid determined in } 1 \mathrm{~g} \text { tested protein }}{\mathrm{mg} \text { of standerd amino acid in } 1 \mathrm{~g} \text { protein }} \times 100
$$

\section{Microbiological analyses}

For examining the microbiological quality of Ricotta cheese, for each sample, $10 \mathrm{~g}$ were weighed out and transferred to a sterile blender with $90 \mathrm{ml}$ of $0.1 \%$ 
peptone and mixed thoroughly for $3 \mathrm{~min}$ to prepare the cheese homogenate. These were then checked for the total bacteria count, Coliform count and the presence of mold and yeast.

Total viable bacterial count( TBVC) per gram of Ricotta cheese samples was determined by plating suitable dilutions in duplicate on plate Count Agar medium (Tryptone Gluccose Yeast Agar) according to American Public Health Association (APHA, 2004). The plates were incubated at $32^{\circ} \mathrm{C}$ for 48 hours before counting and recording the results.

Molds\& Yeasts count were determined on Oxytetracycline- Glucose-Yeast Extract Agar (OGYE Agar ) medium according to IDF, 1990. The plates were incubated at $25-27^{\circ} \mathrm{C}$ for 4 days.

Coliform count was enumerated using Violet Red Bile Agar medium as reported by American Public Health Association (APHA, 2004). The plates were incubated at $37^{\circ} \mathrm{C}$ for 48 hours.

\section{Antioxidant Activity:}

Antioxidant activity was measured using the ferric antioxidant power (FRAP) assay of Benzie and Strain (1996).

\section{Sensory evaluation}

The organoleptic properties of different Ricotta cheese samples were evaluated by a taste panel of 12 panelists in Dairy Chemistry Department, Animal Production Research Institute, Dokki, Cairo, Egypt. according to Mahran et al. (1999).

\section{Statistical analysis}

The data obtained (mean of three replicates) were statistically analyzed according to statistical analyses system user's guide (SAS, 1996).

\section{RESULTS AND DISCUSSION}

\section{Chemical composition:}

The chemical composition of sweet whey, buttermilk, orange juice and orange peel + pulp before preparation were shown in Table (1). The orange peel and pulp was the highest in protein, ash, carbohydrate, caratenoids and flavonoids content compared to buttermilk, sweet whey and orange juice. Also, those contained dietary fiber and pectin, (Table 1). 
Table 2. The chemical composition Ricotta cheeses fortified with different level of Peel and pulp Citrus sinensis during storage at $5 \pm 1^{\circ} \mathrm{C}$.

\begin{tabular}{|c|c|c|c|c|c|c|c|c|}
\hline \multirow{4}{*}{$\begin{array}{c}\text { Component } \\
(\%)\end{array}$} & \multicolumn{8}{|c|}{ Treatments } \\
\hline & \multicolumn{4}{|c|}{ Whey ricotta cheese (WRC) } & \multicolumn{4}{|c|}{ Butter milk ricotta cheese (BRC) } \\
\hline & \multicolumn{8}{|c|}{ Levels of supplementing with Citrus sinensis (\%) } \\
\hline & Control & 1 & 3 & 5 & Control & 1 & 3 & 5 \\
\hline $\begin{array}{c}\text { Total Solids } \\
\text { (\%) }\end{array}$ & $21.76^{\mathrm{a}, \mathrm{b}}$ & $19.11^{\mathrm{b}, \mathrm{b}}$ & $16.40^{c, b}$ & $13.82^{\mathrm{d}, \mathrm{b}}$ & $29.86^{\mathrm{a}, \mathrm{a}}$ & $26.81^{\mathrm{b}, \mathrm{a}}$ & $23.87^{c, a}$ & $19.92^{\mathrm{d}, \mathrm{a}}$ \\
\hline Fat $(\%)$ & $0.50^{\mathrm{a}, \mathrm{b}}$ & $0.48^{\mathrm{b}, \mathrm{b}}$ & $0.47^{\mathrm{b}, \mathrm{b}}$ & $0.45^{\mathrm{b}, \mathrm{b}}$ & $0.75^{\mathrm{a}, \mathrm{a}}$ & $0.62^{\mathrm{b}, \mathrm{a}}$ & $0.60^{b, a}$ & $0.59^{b, a}$ \\
\hline $\begin{array}{c}\text { Total Protein } \\
(\%)\end{array}$ & $12.87^{a, b}$ & $12.40^{\mathrm{b}, \mathrm{b}}$ & $10.91^{c, b}$ & $9.34^{\mathrm{d}, \mathrm{b}}$ & $17.04^{\mathrm{a}, \mathrm{a}}$ & $14.63^{\mathrm{b}, \mathrm{a}}$ & $13.23^{c, a}$ & $11.64^{\mathrm{d}, \mathrm{a}}$ \\
\hline Fiber $(\%)$ & - & $0.89^{c, a}$ & $2.73^{\mathrm{b}, \mathrm{a}}$ & $4.58^{\mathrm{a}, \mathrm{a}}$ & - & $0.82^{\mathrm{c}, \mathrm{b}}$ & $2.69^{\mathrm{b}, \mathrm{b}}$ & $4.52^{\mathrm{a}, \mathrm{b}}$ \\
\hline Ash \% & $1.87^{\mathrm{a}, \mathrm{b}}$ & $1.76^{a, b}$ & $1.64^{\mathrm{a}, \mathrm{b}}$ & $1.54^{\mathrm{a}, \mathrm{b}}$ & $1.61^{\mathrm{a}, \mathrm{a}}$ & $1.40^{\mathrm{a}, \mathrm{a}}$ & $1.38^{\mathrm{a}, \mathrm{a}}$ & $1.37^{\mathrm{a}, \mathrm{a}}$ \\
\hline
\end{tabular}

The letters before comma possess the factor of orange level. While those after comma possess the factor of the kind ricotta cheese. The means with the same letter at any position were not significantly different $(P>0.05)$.

The data in Table 2 showed that the total solids of Ricotta cheese made from sweet buttermilk were higher that of Ricotta cheese made from sweet whey. That returned to the water binding capacity of whey proteins and the low percentage of protein in cheese whey. On the other hand, adding orange peel and pulp rates $1 \%$, $3 \%$, and $5 \%$ led to significant differences $(P<0.0001)$ in the total solids (T.S) contents of the resultant Ricotta cheese according to the addition level of Citrus sinensis.

With regard to the fat, total protein, and ash contents of Ricotta cheese, data illustrated in Table (2) confirmed that, the fat, total protein and ash contents increased significantly $(P<0.0001)$ as the adding level with Citrus sinensis decreased. while the fiber content increased significantly $(P<0.001)$ by increasing the level of Citrus sinensis.

\section{Loss and Recovery of protein:}

Loss and recovery of protein in fresh Ricotta cheese made from cheese whey or buttermilk fortified with different levels of Citrus sinensis were shown in Table (3).Loss protein content of different whey fresh Ricotta cheeses were 35.21,26.19, 15.54 and 6.87 for control, $1 \%, 3 \%$ and $5 \%$ of Citrus sinensis respectively. While loss protein content of different buttermilk fresh Ricotta cheeses were 29.15,21.81, 10.90 and 4.36 for control, $1 \%, 3 \%$ and $5 \%$ of Citrus sinensis respectively. 
Table 3. Loss and recovery of protein in Ricotta cheeses fortified with different levels of Peel and pulp Citrus sinensis

\begin{tabular}{|c|c|c|c|c|c|c|c|c|}
\hline \multirow{4}{*}{$\begin{array}{c}\text { Content } \\
\%\end{array}$} & \multicolumn{8}{|c|}{ Treatments } \\
\hline & \multicolumn{4}{|c|}{ Whey ricotta cheese (WRC) } & \multicolumn{4}{|c|}{ Butter milk ricotta cheese (BRC) } \\
\hline & \multicolumn{8}{|c|}{ Levels of supplementing with Citrus sinensis (\%) } \\
\hline & Control & 1 & 3 & 5 & Control & 1 & 3 & 5 \\
\hline Protein loss \% & $35.21^{\mathrm{a}, \mathrm{a}}$ & $26.19^{b, a}$ & $15.54^{\mathrm{c}, \mathrm{a}}$ & $6.87^{\mathrm{d}, \mathrm{a}}$ & $29.15^{a, b}$ & $21.81^{\mathrm{b}, \mathrm{b}}$ & $10.90^{\mathrm{c}, \mathrm{b}}$ & $4.36^{\mathrm{d}, \mathrm{b}}$ \\
\hline $\begin{array}{c}\text { Recovery of } \\
\text { protein\% }\end{array}$ & $64.79^{d, b}$ & $73.81^{c, b}$ & $84.46^{\mathrm{b}, \mathrm{b}}$ & $93.13^{a, b}$ & $70.85^{d, a}$ & $78.19^{c, a}$ & $89.10^{\mathrm{b}, \mathrm{a}}$ & $95.64^{\mathrm{a}, \mathrm{a}}$ \\
\hline
\end{tabular}

The letters before comma possess the factor of orange level. While those after comma possess the factor of the kind Ricotta cheese. The means with the same letter at any position were not significantly different $(P>0.05)$.

The data in Table (3) indicated that the addition of orange peel and pulp in whey Ricotta cheese and buttermilk Ricotta cheese which caused significant decrease in loss of protein \%. That could be due to the dietery fiber (DF) which had desirable functional properties, such as improving texture, gelling, thickening, emulsification, and stabilization in DF-enriched foods (Nelson, 2001).

Data illustrated in Table (3) showed that buttermilk Ricotta cheese had the lowest protein loss $\%$. This may be due to better binding and cross-linking properties of casein, introduced into the system in the form of buttermilk solids which coprecipitated with whey protein. Similar result was observed by Mahran et. al. (1999). They reported that Ricotta cheese from $100 \%$ whey showed lowest protein recovery than those made with different levels of added skim milk powder.

\section{Cheese yield:}

Yield \% of Ricotta cheese samples whether made from cheese whey or sweet buttermilk and fortified with different level of peel and pulp Citrus sinensis when fresh and during storage at $5 \pm 1^{\circ} \mathrm{C}$ are presented in Table (4). The yield of different treatments for buttermilk Ricotta cheese were higher than whey Ricotta cheese. Control Ricotta cheese made from cheese whey was the lowest values when fresh and during storage period. That was due to the solid scontent in whey Ricotta cheese compairing with buttermilk ricotta cheese. This agreed with Mahran et. al., (1999), who reported that, addition of different levels of skim milk powder to whey caused a significant and gradual increase in the yield of Ricotta cheese, due to the increase in the solids especially in protein. There were significant differences $(P<0.0001)$ between whey Ricotta cheese treatments and buttermilk Ricotta cheese treatments. Also, the 
addition of peel and pulp Citrus sinensis led to increase yield \%. The results also showed that increasing the ratio added of peel and pulp Citrus sinensis caused significant increase in yield $\%$, which could be due to the effect of dietery fiber as mentioned before.

It was noticed that, the yield of all Ricotta cheese samples slightly decreased with increasing the storage period. The decreased during cold storage in different types of cheese such as cottage cheese was reported by Aylward et. al., (1980).

Table 4. Yield \% of Ricotta cheeses fortified with different levels of peel and pulp Citrus sinensis when fresh and during storage at $5 \pm 1^{\circ} \mathrm{C}$.

\begin{tabular}{|c|c|c|c|c|c|c|c|c|}
\hline \multirow{4}{*}{$\begin{array}{c}\text { Cold } \\
\text { storage } \\
\text { period } \\
\text { (days) }\end{array}$} & \multicolumn{8}{|c|}{ Treatments } \\
\hline & \multicolumn{4}{|c|}{ Whey Ricotta cheese (WRC) } & \multicolumn{4}{|c|}{ Buttermilk Ricotta cheese (BRC) } \\
\hline & \multicolumn{8}{|c|}{ Levels of supplementing with Citrus sinensis(\%) } \\
\hline & Control & 1 & 3 & 5 & Control & 1 & 3 & 5 \\
\hline 1 & $7.65^{\mathrm{d}, \mathrm{b}, \mathrm{a}}$ & $16.89^{c, b, a}$ & $48.32^{b, b, a}$ & $67.79^{a, b, a}$ & $26.21^{\mathrm{d}, \mathrm{a}, \mathrm{a}}$ & $41.22^{\mathrm{c}, \mathrm{a}, \mathrm{a}}$ & $68.55^{b, a, a}$ & $88.13^{\mathrm{a}, \mathrm{a}, \mathrm{a}}$ \\
\hline 8 & $7.64^{d, b, a}$ & $16.89^{c, b, a}$ & $48.32^{b, b, a}$ & $67.79^{a, b, a}$ & $26.21^{\mathrm{d}, \mathrm{a}, \mathrm{a}}$ & $41.22^{\mathrm{c}, \mathrm{a}, \mathrm{a}}$ & $68.55^{\mathrm{b}, \mathrm{a}, \mathrm{a}}$ & $88.13^{\mathrm{a}, \mathrm{a}, \mathrm{a}}$ \\
\hline 15 & $7.63^{\mathrm{d}, \mathrm{b}, \mathrm{a}}$ & $16.88^{c, b, a}$ & $48.32^{b, b, a}$ & $67.79^{a, b, a}$ & $26.19^{d, a, a}$ & $41.21^{\mathrm{c}, \mathrm{a}, \mathrm{a}}$ & $68.55^{\mathrm{b}, \mathrm{a}, \mathrm{a}}$ & $88.13^{\mathrm{a}, \mathrm{a}, \mathrm{a}}$ \\
\hline 22 & $7.61^{d, b, b}$ & $16.88^{c, b, b}$ & $48.31^{b, b, b}$ & $67.79^{a, b, b}$ & $26.18^{\mathrm{d}, \mathrm{a}, \mathrm{b}}$ & $41.21^{c, a, b}$ & $68.55^{\mathrm{b}, \mathrm{a}, \mathrm{b}}$ & $88.13^{\mathrm{a}, \mathrm{a}, \mathrm{b}}$ \\
\hline
\end{tabular}

The letters before comma possess the factor of orange level. While those after comma possess the factor of the kind Ricotta cheese and storage period, respectively. The means with the same letter at any position were not significantly different $(P>0.05)$.

\section{Amino acid content:}

The amino acid composition of protein plays an important role in determining the biological and nutritive value of protein. As the nutritional value of the experimental cheeses will be reflected by its composition of essential amino acids when compared to recommendation of the united nations. The amino acids expressed as $\mathrm{mg} / \mathrm{g}$ protein are shown in Table (5).

The results show that, lysine and threonine are excess in whey Ricotta cheese treatments compared with the other buttermilk Ricotta cheese treatments. These result are in line with the finding of Rodney and Ernstrom (1982). Who mentioned that, the relatively higher content of lysine and threonine in whey Ricotta cheese may be due to the fact that, the dominating protein in milk Ricotta cheese is nutritionally less than cheese whey protein.

Data in Table 5 reveal that, phenylalanine and tyrosine are relatively low in whey Ricotta cheese compared with Ricotta cheese treatments made from buttermilk. 
Data showed that, supplementation with peel and pulp Citrus sinensis did not cause any significant differences $(P<0.05)$ in the essential amino acids and non essential amino acids content of all Ricotta treatments. While There were significant differences $(P<0.0001)$ between whey Ricotta cheese treatments and buttermilk Ricotta cheese treatments.

The above results show that, the essential amino acids and non essential amino acids contents of the Ricotta cheese obtained are in adequate with the recommendations of the FAO/WHO and the united Nations organizations (1985).

Table 5. Amino acids of Ricotta cheeses fortified with different levels of peel and pulp Citrus sinensis

\begin{tabular}{|c|c|c|c|c|c|c|c|c|}
\hline \multirow{4}{*}{ Amino acid } & \multicolumn{8}{|c|}{ Treatments } \\
\hline & \multicolumn{4}{|c|}{ Whey Ricotta cheese (WRC) } & \multicolumn{4}{|c|}{ Butter milk Ricotta cheese (BRC) } \\
\hline & \multicolumn{8}{|c|}{ Levels of supplementing with Citrus sinensis (\%) } \\
\hline & Control & 1 & 3 & 5 & Control & 1 & 3 & 5 \\
\hline & \multicolumn{8}{|c|}{ Essential Amino acids (mg/g protein) } \\
\hline Leucine & $60.10^{\mathrm{d}, \mathrm{b}}$ & $60.28^{c, b}$ & $60.63^{\mathrm{a}, \mathrm{b}}$ & $61.01^{\mathrm{b}, \mathrm{b}}$ & $65.88^{\mathrm{d}, \mathrm{a}}$ & $66.07^{c, a}$ & $66.42^{\mathrm{a}, \mathrm{a}}$ & $66.78^{b, a}$ \\
\hline Isoleucine & $43.11^{\mathrm{a}, \mathrm{b}}$ & $43.26^{\mathrm{a}, \mathrm{b}}$ & $43.54^{a, b}$ & $43.88^{a, b}$ & $48.69^{a, a}$ & $48.76^{\mathrm{a}, \mathrm{a}}$ & $49.03^{a, a}$ & $49.34^{a, a}$ \\
\hline Lysine & $98.80^{d, a}$ & $99.11^{\mathrm{c}, \mathrm{a}}$ & $99.70^{\mathrm{b}, \mathrm{a}}$ & $100.32^{\mathrm{a}, \mathrm{a}}$ & $68.77^{\mathrm{d}, \mathrm{b}}$ & $69.04^{c, b}$ & $69.65^{b, b}$ & $69.97^{a, b}$ \\
\hline Valine & $56.42^{d, b}$ & $56.71^{\mathrm{c}, \mathrm{b}}$ & $57.30^{\mathrm{b}, \mathrm{b}}$ & $57.89^{a, b}$ & $58.76^{\mathrm{d}, \mathrm{a}}$ & $59.05^{c, a}$ & $59.63^{\mathrm{b}, \mathrm{a}}$ & $60.23^{a, a}$ \\
\hline Therionine & $56.70^{d, a}$ & $56.81^{c, a}$ & $57.04^{\mathrm{b}, \mathrm{a}}$ & $57.26^{a, a}$ & $42.63^{\mathrm{d}, \mathrm{b}}$ & $42.74 c, b$ & $42.97^{b, b}$ & $43.22^{a, b}$ \\
\hline Phenylalanine & $39.94^{d, b}$ & $40.14^{c, b}$ & $40.56^{a, b}$ & $40.99^{b, b}$ & $48.11^{\mathrm{d}, \mathrm{a}}$ & $48.30^{c, a}$ & $48.72^{\mathrm{a}, \mathrm{a}}$ & $49.15^{b, a}$ \\
\hline Histidine & $21.29^{\mathrm{a}, \mathrm{b}}$ & $21.42^{\mathrm{a}, \mathrm{b}}$ & $21.70^{\mathrm{a}, \mathrm{b}}$ & $21.99^{a, b}$ & $36.95^{\mathrm{a}, \mathrm{a}}$ & $37.08^{\mathrm{a}, \mathrm{a}}$ & $37.36^{\mathrm{a}, \mathrm{a}}$ & $37.65^{a, a}$ \\
\hline \multirow[t]{2}{*}{ Arginine } & $20.35^{a, b}$ & $20.94^{\mathrm{a}, \mathrm{b}}$ & $22.16^{a, b}$ & $23.38^{a, b}$ & $28.49^{a, a}$ & $29.09^{a, a}$ & $30.29^{a, a}$ & $31.52^{\mathrm{a}, \mathrm{a}}$ \\
\hline & \multicolumn{8}{|c|}{ Non- essential Amino acids (mg/g protein) } \\
\hline Aspartic acid & $70.19^{\mathrm{b}, \mathrm{a}}$ & $71.29^{\mathrm{ab}, \mathrm{a}}$ & $73.51^{\mathrm{ab}, \mathrm{a}}$ & $75.74^{\mathrm{a}, \mathrm{a}}$ & $66.26^{\mathrm{b}, \mathrm{b}}$ & $67.35^{\mathrm{ab}, \mathrm{b}}$ & $69.57^{\mathrm{ab}, \mathrm{b}}$ & $71.80^{\mathrm{a}, \mathrm{b}}$ \\
\hline Glutamic acid & $\underset{b}{172.40^{d}}$ & $173.15^{\mathrm{b}, \mathrm{b}}$ & $174.66^{\mathrm{a}, \mathrm{b}}$ & $176.18^{\mathrm{c}, \mathrm{b}}$ & $208.76^{a, a}$ & $209.50^{\mathrm{b}, \mathrm{a}}$ & $211.03^{\mathrm{a}, \mathrm{a}}$ & $212.54^{c, a}$ \\
\hline Serine & $41.19^{c, b}$ & $43.01^{b c, b}$ & $46.63^{a b, b}$ & $50.17^{a, b}$ & $43.41^{c, a}$ & $45.20^{\mathrm{bc}, \mathrm{a}}$ & $48.75^{a b, a}$ & $52.37^{a, a}$ \\
\hline Glycine & $23.19^{d, a}$ & $23.74^{c, a}$ & $24.85^{b, a}$ & $25.98^{\mathrm{a}, \mathrm{a}}$ & $18.63^{\mathrm{d}, \mathrm{b}}$ & $19.18^{c, b}$ & $20.28^{b, b}$ & $21.30^{\mathrm{a}, \mathrm{b}}$ \\
\hline Tyrosine & $33.72^{\mathrm{c}, \mathrm{b}}$ & $33.84^{\mathrm{b}, \mathrm{b}}$ & $34.10^{a, b}$ & $34.36^{\mathrm{d}, \mathrm{b}}$ & $47.17^{c, a}$ & $47.29^{\mathrm{b}, \mathrm{a}}$ & $47.53^{\mathrm{a}, \mathrm{a}}$ & $47.79^{\mathrm{d}, \mathrm{a}}$ \\
\hline Alanine & $31 . .33^{\mathrm{d}, \mathrm{a}}$ & $31.69^{c, a}$ & $32.42^{\mathrm{b}, \mathrm{a}}$ & $33.15^{a, a}$ & $27.25^{\mathrm{d}, \mathrm{b}}$ & $27.63^{c, b}$ & $28.36^{\mathrm{b}, \mathrm{b}}$ & $29.09^{a, b}$ \\
\hline Proline & $40.45^{d, b}$ & $40.95^{c, b}$ & $41.96^{\mathrm{b}, \mathrm{b}}$ & $42.94^{a, b}$ & $45.07^{d, a}$ & $45.56^{c, a}$ & $46.58^{\mathrm{b}, \mathrm{a}}$ & $47.59^{a, a}$ \\
\hline
\end{tabular}

The letters before comma possess the factor of orange level. While those after comma possess the factor of the kind Ricotta cheese. The means with the same letter at any position were not significantly different $(P>0.05)$. 


\section{Chemical score:}

Amino acid scores (AAS) were calculated using FAO/WHO (1973). Scoring pattern. It is clear from Table (6) that, the essential amino acids are in excess in all cheeses under investigation compared to the FAO provisional pattern.

The resultant Ricotta cheeses obtained showed satisfactory amino acid scores. Since the FAO pattern is formulated to cover the amino acid requirements of all ages except infants. The highest score was shown by Ricotta cheese made from buttermilk.

The data revealed that whey Ricotta cheese had the highest content of lysine and threonine.

Table 6. Amino acids Scores (AAS), protein efficiency ratio (PER) and biological value (BV) of the different Ricotta cheeses fortified with different levels of peel and pulp Citrussinensis.

\begin{tabular}{|c|c|c|c|c|c|c|c|c|c|}
\hline \multirow{5}{*}{\multicolumn{2}{|c|}{$\begin{array}{l}\text { Essential amino acid } \\
\text { References protein FAO/ } \\
\text { WHO } 1985\end{array}$}} & \multicolumn{8}{|c|}{ Treatments } \\
\hline & & \multicolumn{8}{|c|}{ Whey Ricotta cheese (WRC) } \\
\hline & & \multicolumn{8}{|c|}{ Levels of supplementing with Citrus sinensis (\%) } \\
\hline & & \multicolumn{2}{|c|}{ Control } & \multicolumn{2}{|c|}{1} & \multicolumn{2}{|c|}{3} & \multicolumn{2}{|c|}{5} \\
\hline & & \multirow{2}{*}{$\begin{array}{c}\text { Value } \\
103.21\end{array}$} & \multirow{2}{*}{$\begin{array}{c}\text { Score } \\
92.15^{\mathrm{c}, \mathrm{b}}\end{array}$} & \multirow{2}{*}{$\begin{array}{l}\text { Value } \\
103.54\end{array}$} & \multirow{2}{*}{$\begin{array}{c}\text { Score } \\
92.45^{\mathrm{b}, \mathrm{b}}\end{array}$} & \multirow{2}{*}{$\begin{array}{l}\text { Value } \\
104.17\end{array}$} & \multirow{2}{*}{$\begin{array}{l}\text { Score } \\
93.01^{\mathrm{a}, \mathrm{b}}\end{array}$} & \multirow{2}{*}{$\begin{array}{l}\text { Value } \\
104.89\end{array}$} & \multirow{2}{*}{$\begin{array}{c}\text { Score } \\
93.65^{\mathrm{d}, \mathrm{b}}\end{array}$} \\
\hline $\begin{array}{c}\text { Leucine } \\
+ \text { Isoleucine }\end{array}$ & 112.0 & & & & & & & & \\
\hline Lysine & 51.0 & 98.80 & $193.73^{\mathrm{d}, \mathrm{a}}$ & 99.11 & $194.33^{c, a}$ & 99.70 & $195.49^{\mathrm{b}, \mathrm{a}}$ & 100.32 & $196.71^{\mathrm{a}, \mathrm{a}}$ \\
\hline Valine & 48.0 & 56.42 & $117.54^{\mathrm{d}, \mathrm{b}}$ & 56.71 & $118.15^{\mathrm{b}, \mathrm{b}}$ & 57.30 & $119.38^{a, b}$ & 57.89 & $120.60^{c, b}$ \\
\hline Therionine & 35.0 & 56.70 & $162.0^{\mathrm{c}, \mathrm{aa}}$ & 56.81 & $162.31^{\mathrm{bc}, \mathrm{a}}$ & 57.04 & $162.97^{\mathrm{b}, \mathrm{a}}$ & 57.26 & $163.60^{\mathrm{a}, \mathrm{a}}$ \\
\hline Phenylalanine & 73.0 & 39.94 & $54.71^{\mathrm{c}, \mathrm{b}}$ & 40.14 & $54.99^{\mathrm{b}, \mathrm{b}}$ & 40.56 & $55.56^{\mathrm{a}, \mathrm{b}}$ & 40.99 & $56.15^{\mathrm{d}, \mathrm{b}}$ \\
\hline Histidine & 17.1 & 21.29 & $124.50^{c, b}$ & 21.42 & $125.26^{\mathrm{b}, \mathrm{b}}$ & 21.70 & $126.90^{\mathrm{a}, \mathrm{b}}$ & 21.99 & $128.60^{\mathrm{d}, \mathrm{b}}$ \\
\hline PER & 3.2 & & & & & & & & \\
\hline $\begin{array}{c}\text { PER } \\
\text { Calculated }\end{array}$ & & & & & & & & & \\
\hline BV & 83.60 & & & & & & & & \\
\hline \multirow[t]{2}{*}{ BV Caculated } & & \multicolumn{2}{|c|}{$70.12^{\mathrm{d}, \mathrm{a}}$} & \multicolumn{2}{|c|}{$67.59^{c, a}$} & \multicolumn{2}{|c|}{$62.33^{b, a}$} & \multicolumn{2}{|c|}{$57.48^{\mathrm{a}, \mathrm{a}}$} \\
\hline & & \multicolumn{8}{|c|}{ Butter milk Ricotta cheese (BRC) } \\
\hline $\begin{array}{c}\text { Leucine } \\
\text { +Isoleucine }\end{array}$ & 112.0 & 114.57 & $102.29^{c, a}$ & 114.83 & $102.53^{\mathrm{b}, \mathrm{a}}$ & 115.45 & $103.08^{\mathrm{a}, \mathrm{a}}$ & 116.12 & $\underset{, a}{103.68^{d}}$ \\
\hline Lysine & 51.0 & 68.77 & $134.84^{\mathrm{d}, \mathrm{b}}$ & 69.04 & $138.94^{c, b}$ & 69.65 & $147.04^{\mathrm{b}, \mathrm{b}}$ & 69.97 & $155.18^{\mathrm{a}}$ \\
\hline Valine & 48.0 & 58.76 & $122.42^{\mathrm{d}, \mathrm{a}}$ & 59.05 & $126.85^{\mathrm{b}, \mathrm{a}}$ & 59.63 & $135.38^{\mathrm{a}, \mathrm{a}}$ & 60.23 & $143.90^{c}$ \\
\hline Therionine & 35.0 & 42.63 & $121.8^{\mathrm{c}, \mathrm{b}}$ & 42.74 & $122.11^{\mathrm{bc}, \mathrm{b}}$ & 42.97 & $122.77^{\mathrm{b}, \mathrm{b}}$ & 43.22 & $123.49^{\mathrm{a}}$ \\
\hline Phenylalanine & 73.0 & 48.11 & $65.90^{c, a}$ & 48.30 & $67.96^{\mathrm{b}, \mathrm{a}}$ & 48.72 & $72.04^{\mathrm{a}, \mathrm{a}}$ & 49.15 & $76.18^{d, a}$ \\
\hline Histidine & 17.1 & 36.95 & $216.08^{c, a}$ & 37.08 & $221.75^{\mathrm{b}, \mathrm{a}}$ & 37.36 & $233.51^{\mathrm{a}, \mathrm{a}}$ & 37.65 & $245.38^{d}$ \\
\hline PER & 3.2 & & & & & & & & \\
\hline $\begin{array}{c}\text { PER } \\
\text { Calculated }\end{array}$ & & \multicolumn{2}{|c|}{$1.56^{a, b}$} & \multicolumn{2}{|c|}{$1.33^{\mathrm{b}, \mathrm{b}}$} & \multicolumn{2}{|c|}{$0.83^{c, b}$} & \multicolumn{2}{|c|}{$0.34^{\mathrm{d}, \mathrm{b}}$} \\
\hline BV & 83.60 & & & & & & & & \\
\hline BV Caculated & & \multicolumn{2}{|c|}{$66.33^{d, b}$} & \multicolumn{2}{|c|}{$63.90^{c, b}$} & \multicolumn{2}{|c|}{$58.64^{b, b}$} & \multicolumn{2}{|c|}{$53.48^{\mathrm{ab}, \mathrm{b}}$} \\
\hline
\end{tabular}

The letters before comma possess the factor of orange level. While those after comma possess the factor of the kind Ricotta cheese. The means with the same letter at any position were not significantly different $(P>0.05)$. 
Also, data in Table (6) indicated that Ricotta cheese whether made from sweet whey or buttermilk and fortified with levels of peel and pulp Citrus sinensis showed higher values than control.

Furthermore, the Ricotta cheese fortified with levels of peel and pulp Citrus sinensis showed positive relationship between the proportion of amino acid scores and the proportion of peel and pulp Citrus sinensis used.

\section{Protein efficiency ratio (PER) and Biological value (BV):}

It is clear from Table (6) that, the PER were low in the cheeses under investigation compared to the FAO provisional pattern (3.2), being, 1.92, 1.68, 1.18 and 0.72 for control, $1 \%$ Citrus sinensis, 3\% Citrus sinensis, $5 \%$ Citrus sinensis of whey Ricotta cheeses respectively. 1.56, 1.33, 0.83 , and 0.34 for control, $1 \%$ Citrus sinensis, 3\% Citrus sinensis, $5 \%$ Citrus sinensi $s$ of buttermilk Ricotta cheeses respectively.

The highest value of protein efficiency ratio of control whey Ricotta cheese was due to its well balanced amino acid (Forsum, 1974).

The highest BV for whey Ricotta cheese may be due to exess PER of whey Ricotta. The values were 70.12, 67.59, 62.33 and 57.48 for control, $1 \%$ Citrus sinensis, 3\% Citrus sinensis, 5\% Citrus sinensis of whey Ricotta cheeses respectively. While they were $66.33,63.90,58.64$ and 53.48 for control, $1 \%$ Citrus sinensis, 3\% Citrus sinensis, $5 \%$ Citrus sinensis of buttermilk Ricotta cheeses respectively.

Generally, all the results were significantly different $(P<0.0001)$.

\section{Ferric Redusing Antioxidant power (FRAP)}

Table (7) Showed that fortification of different Ricotta cheese with peel and pulp Citrus sinensis powder proportionally increased the ferric reducing antioxidant power FRAPS values of the resultant fresh Ricotta cheese by increasing the percent of addition. This ascribed to the ferric reducing antioxidant power FRAP assay which permits the overall estimation of water - soluble compounds influencing the total antioxidant. The rate of increase in ferric reducing antioxidant power FRAP values for fresh Ricotta cheese samples fortified with peel and pulp Citrus sinensis powder was $5 \%, 3 \%$ for buttermilk Ricotta cheese samples respectively then, $5 \%, 3 \%$ for whey Ricotta cheese samples respectively after then, $1 \%$ for buttermilk Ricotta cheese sample finaly, $1 \%$ for whey Ricotta cheese sample. Also, it is noteworthy that the reducing power of control cheese samples whether whey Ricotta cheese or buttermilk Ricotta cheese were more affected by storage rather than the fortified samples. After 22 days, the ferric reducing antioxidant power FRAP values of cheese samples 5\%, and $3 \%$ were significantly more by $55,48,44$ and 39 than the corresponding value of other Ricotta cheese treatments and control cheese. 
The results of Table ( 7$)$ showed, different significant $(P<0.0001)$ in ferric reducing antioxidant power FRAPS values between treatments and kinds of Ricotta cheese whether made from whey cheese or made from buttermilk.

These results in Table (7) are agreed with those found by (Hegazy and Ibrahium, 2012).

Table 7. Ferric Reducing Antioxidant Power FRAP (mmol FeSo4/l) of Ricotta cheeses fortified with different levels of peel and pulp Citrus sinensis when fresh and during storage at $5 \pm 1^{\circ} \mathrm{C}$.

\begin{tabular}{|c|c|c|c|c|c|c|c|c|}
\hline \multirow{4}{*}{$\begin{array}{c}\text { Cold } \\
\text { storage } \\
\text { period } \\
\text { (days) } \\
\end{array}$} & \multicolumn{8}{|c|}{ Treatments } \\
\hline & \multicolumn{4}{|c|}{ Whey ricotta cheese (WRC) } & \multicolumn{4}{|c|}{ Butter milk ricotta cheese (BRC) } \\
\hline & \multicolumn{8}{|c|}{ Levels of supplementing with Citrus sinensis (\%) } \\
\hline & Control & 1 & 3 & 5 & Control & 1 & 3 & 5 \\
\hline & \multicolumn{8}{|c|}{ Ferric Reducing Antioxidant Power FRAP (mmol FeSo4/I) } \\
\hline 1 & $25^{a, b, a}$ & $44^{b, b, a}$ & $61^{b, b, a}$ & $72^{c, b, a}$ & $38^{\mathrm{a}, \mathrm{a}, \mathrm{a}}$ & $59^{b, a, a}$ & $74^{b, a, a}$ & $89^{c, a, a}$ \\
\hline 8 & $21^{\mathrm{a}, \mathrm{b}, \mathrm{b}}$ & $39^{b, b, b}$ & $53^{b, b, b}$ & $63^{c, b, b}$ & $32^{a, a, b}$ & $51^{b, a, b}$ & $66^{b, a, b}$ & $71^{c, a, b}$ \\
\hline 15 & $17^{\mathrm{a}, \mathrm{b}, \mathrm{c}}$ & $33^{b, b, c}$ & $46^{b, b, c}$ & $54^{c, b, c}$ & $27^{\mathrm{a}, \mathrm{a}, \mathrm{c}}$ & $43^{b, a, c}$ & $57^{b, a, c}$ & $62^{c, a, c}$ \\
\hline 22 & $11^{a, b, d}$ & $27^{b, b, d}$ & $39^{b, b, d}$ & $44^{c, b, d}$ & $21^{a, a, d}$ & $35^{b, a, d}$ & $48^{b, a, d}$ & $51^{c, a, d}$ \\
\hline
\end{tabular}

The letters before comma possess the factor of orange level. While those after comma possess the factor of the kind Ricotta cheese and storage period, respectively. The means with the same letter at any position were not significantly different $(P>0.05)$.

\section{Titratable acidity (\%) and pH value}

Table 8. Titratable acidity and $\mathrm{pH}$ of Ricotta cheeses fortified with different level of peel and pulp Citrus sinensis during storage at $5 \pm 1^{\circ} \mathrm{C}$.

\begin{tabular}{|c|c|c|c|c|c|c|c|c|}
\hline \multirow{4}{*}{$\begin{array}{c}\text { Cold } \\
\text { storage } \\
\text { period } \\
\text { (days) }\end{array}$} & \multicolumn{8}{|c|}{ Treatments } \\
\hline & \multicolumn{4}{|c|}{ Whey ricotta cheese (WRC) } & \multicolumn{4}{|c|}{ Butter milk ricotta cheese (BRC) } \\
\hline & \multicolumn{8}{|c|}{ Levels of supplementing with Citrus sinensis(\%) } \\
\hline & Control & 1 & 3 & 5 & Control & 1 & 3 & 5 \\
\hline & \multicolumn{8}{|c|}{ Titratable acidity } \\
\hline 1 & $0.31^{a, a, c}$ & $0.31^{\mathrm{ab}, \mathrm{a}, \mathrm{c}}$ & $0.30^{\mathrm{bc}, \mathrm{a}, \mathrm{c}}$ & $0.30^{c, a, c}$ & $0.30^{\mathrm{a}, \mathrm{a}, \mathrm{c}}$ & $0.30^{\mathrm{ab}, \mathrm{a}, \mathrm{c}}$ & $0.29^{b c, a, c}$ & $0.29^{c, a, c}$ \\
\hline 8 & $0.37^{a, a, b}$ & $0.36^{\mathrm{ab}, \mathrm{a}, \mathrm{b}}$ & $0.34^{\mathrm{bc}, \mathrm{a}, \mathrm{b}}$ & $0.32^{c, a, b}$ & $0.37^{a, a, b}$ & $0.34^{\mathrm{ab}, \mathrm{a}, \mathrm{b}}$ & $0.32^{\mathrm{bc}, \mathrm{a}, \mathrm{b}}$ & $0.31^{c, a, b}$ \\
\hline 15 & $0.40^{\mathrm{a}, \mathrm{a}, \mathrm{b}}$ & $0.38^{\mathrm{ab}, \mathrm{a}, \mathrm{b}}$ & $0.35^{\mathrm{bc}, \mathrm{a}, \mathrm{b}}$ & $0.33^{c, a, b}$ & $0.39^{\mathrm{a}, \mathrm{a}, \mathrm{b}}$ & $0.36^{a b, a, b}$ & $0.34^{\mathrm{bc}, \mathrm{a}, \mathrm{b}}$ & $0.32^{c, a, b}$ \\
\hline \multirow[t]{2}{*}{22} & $0.44^{\mathrm{a}, \mathrm{a}, \mathrm{a}}$ & $0.40^{\mathrm{ab}, \mathrm{a}, \mathrm{a}}$ & $0.38^{\mathrm{bc}, \mathrm{a}, \mathrm{a}}$ & $0.36^{c, a, a}$ & $0.43^{\mathrm{a}, \mathrm{a}, \mathrm{a}}$ & $0.39^{\mathrm{ab}, \mathrm{a}, \mathrm{a}}$ & $0.37^{\mathrm{bc}, \mathrm{a}, \mathrm{a}}$ & $0.34^{\mathrm{c}, \mathrm{a}, \mathrm{a}}$ \\
\hline & \multicolumn{8}{|c|}{$\mathrm{pH}$} \\
\hline 1 & $6.03^{\mathrm{d}, \mathrm{a}, \mathrm{d}}$ & $6.05^{c, a, d}$ & $6.05^{\mathrm{b}, \mathrm{a}, \mathrm{d}}$ & $6.07^{\mathrm{a}, \mathrm{a}, \mathrm{d}}$ & $6.05^{\mathrm{d}, \mathrm{a}, \mathrm{d}}$ & $6.04^{c, a, d}$ & $6.04^{b, a, d}$ & $6.06^{\mathrm{a}, \mathrm{a}, \mathrm{d}}$ \\
\hline 8 & $5.96^{d, a, c}$ & $5.98^{\mathrm{c}, \mathrm{a}, \mathrm{c}}$ & $6.00^{\mathrm{b}, \mathrm{a}, \mathrm{c}}$ & $6.01^{a, a, c}$ & $5.98^{\mathrm{d}, \mathrm{a}, \mathrm{c}}$ & $5.99^{c, a, c}$ & $6.01^{b, a, c}$ & $6.02^{\mathrm{a}, \mathrm{a}, \mathrm{c}}$ \\
\hline 15 & $5.91^{\mathrm{d}, \mathrm{a}, \mathrm{b}}$ & $5.93^{c, a, b}$ & $5.94^{\mathrm{b}, \mathrm{a}, \mathrm{b}}$ & $5.97^{\mathrm{a}, \mathrm{a}, \mathrm{b}}$ & $5.93^{\mathrm{d}, \mathrm{a}, \mathrm{b}}$ & $5.95^{c, a, b}$ & $5.97^{\mathrm{b}, \mathrm{a}, \mathrm{b}}$ & $5.99^{\mathrm{a}, \mathrm{a}, \mathrm{b}}$ \\
\hline 22 & $5.85^{\mathrm{d}, \mathrm{a}, \mathrm{a}}$ & $5.88^{\mathrm{c}, \mathrm{a}, \mathrm{a}}$ & $5.90^{\mathrm{b}, \mathrm{a}, \mathrm{a}}$ & $5.92^{\mathrm{a}, \mathrm{a}, \mathrm{a}}$ & $5.86^{\mathrm{d}, \mathrm{a}, \mathrm{a}}$ & $5.90^{c, a, a}$ & $5.93^{\mathrm{b}, \mathrm{a}, \mathrm{a}}$ & $5.95^{\mathrm{a}, \mathrm{a}, \mathrm{a}}$ \\
\hline
\end{tabular}

The letters before comma possess the factor of orange level. While those after comma possess the factor of the kind Ricotta cheese and storage period, respectively. The means with the same letter at any position were not significantly different $(P>0.05)$. 
The results of Table (8) showed that, the control whether made from whey or buttermilk had the highest TA\% when fresh, while the treatment with peel and pulp Citrus sinensis at level $5 \%$ had lower value in $\mathrm{TA} \% \mathrm{pH}$ values were the highest with treatments supplemented with Citrus sinensis at level 1\%, 3\% and ccontrol.

Moreover, the level of acidity in Ricotta cheese treatments was significantly the highest $(p<0.0001)$.

The results of Table (8) noticed that, no different significant in acidity or $\mathrm{pH}$ between kinds of Ricotta cheese whether made from whey Ricotta cheese or made from buttermilk cheese.

Generally, the prolonging of cold storage period of Ricotta cheese treatments caused a significant increase $(p<0.0001)$ in TA\% and significant reduction $(p<0.0001)$ in $\mathrm{pH}$ value.

\section{The antimicrobial activity of Citrus sinensis:}

The results in Table (9) show the TBC and Mould \& Yeast counts in the different Ricotta cheeses fortified with different levels of Citrus sinensis during 22 days at $\left(5 \pm 1^{\circ} \mathrm{C}\right)$.

The TBC in different fresh whey Ricotta cheese samples were $2.11,1.94,1.86$ and $1.70(\log \mathrm{cfu} / \mathrm{g})$ for control, $1 \%, 3 \%$ and 5\%Citrus sinensis respectively. While,the TBC in different fresh buttermilk Ricotta cheese samples were 2.01, 1.86, 1.76 and 1.62 (log cfu/g) for control, $1 \%, 3 \%$ and $5 \%$ peel and pulp Citrus sinensis respectively.

The results indicated that, control Ricotta cheese samples whether made from whey or from buttermilk had highest total bacterial counts compared to all cheese treatments when fresh and during cold storage.

Molds and Yeasts were not detected in fresh control cheese and up to 8 days of cold storage, while, in other treatments were not detected either when fresh or during the storage period. This may be due to the antioxidant and antimicrobial activities (Mamta and Parminder, 2013). 
Table 9. Microbiological counts(log CFU/ $\mathrm{mL}$ ) of Ricotta cheeses fortified with different levels of peel and pulp Citrus sinensis during storage at $5 \pm 1^{\circ} \mathrm{C}$.

\begin{tabular}{|c|c|c|c|c|c|c|c|c|}
\hline Cold & \multicolumn{8}{|c|}{ Treatments } \\
\hline storage & \multicolumn{4}{|c|}{ Whey ricotta cheese (WRC) } & \multicolumn{4}{|c|}{ Butter milk ricotta cheese (BRC) } \\
\hline period & \multicolumn{8}{|c|}{ Levels of supplementing with Citrus sinensis (\%) } \\
\hline (days) & Control & 1 & 3 & 5 & Control & 1 & 3 & 5 \\
\hline & \multicolumn{8}{|c|}{ Total bacterial counts (log CFU /g) } \\
\hline 1 & $2.11^{\mathrm{a}, \mathrm{a}, \mathrm{c}}$ & $1.94^{\mathrm{b}, \mathrm{a}, \mathrm{c}}$ & $1.86^{\mathrm{c}, \mathrm{a}, \mathrm{c}}$ & $1.70^{\mathrm{d}, \mathrm{a}, \mathrm{c}}$ & $2.01^{\mathrm{a}, \mathrm{a}, \mathrm{c}}$ & $1.86^{\mathrm{b}, \mathrm{a}, \mathrm{c}}$ & $1.76^{\mathrm{c}, \mathrm{a}, \mathrm{c}}$ & $1.62^{\mathrm{d}, \mathrm{a}, \mathrm{c}}$ \\
\hline 8 & $2.39^{a, a, b c}$ & $2.17^{\mathrm{b}, \mathrm{a}, \mathrm{bc}}$ & $2.02^{c, a, b c}$ & $1.83^{\mathrm{d}, \mathrm{a}, \mathrm{bc}}$ & $2.28^{\mathrm{a}, \mathrm{a}, \mathrm{bc}}$ & $2.10^{\mathrm{b}, \mathrm{a}, \mathrm{bc}}$ & $1.96^{c, a, b c}$ & $1.75^{\mathrm{d}, \mathrm{a}, \mathrm{bc}}$ \\
\hline 15 & $2.52^{a, a, b}$ & $2.28^{\mathrm{b}, \mathrm{a}, \mathrm{b}}$ & $2.11^{\mathrm{c}, \mathrm{a}, \mathrm{b}}$ & $1.90^{\mathrm{d}, \mathrm{a}, \mathrm{b}}$ & $2.41^{\mathrm{a}, \mathrm{a}, \mathrm{b}}$ & $2.22^{\mathrm{b}, \mathrm{a}, \mathrm{b}}$ & $2.05^{\mathrm{c}, \mathrm{a}, \mathrm{b}}$ & $1.82^{d, a, b}$ \\
\hline 22 & $2.88^{\mathrm{a}, \mathrm{a}, \mathrm{a}}$ & $2.52^{\mathrm{b}, \mathrm{a}, \mathrm{a}}$ & $2.30^{\mathrm{c}, \mathrm{a}, \mathrm{a}}$ & $2.01^{d, a, a}$ & $2.72^{\mathrm{a}, \mathrm{a}, \mathrm{a}}$ & $2.46^{\mathrm{b}, \mathrm{a}, \mathrm{a}}$ & $2.18^{\mathrm{c}, \mathrm{a}, \mathrm{a}}$ & $1.81^{\mathrm{d}, \mathrm{a}, \mathrm{a}}$ \\
\hline & \multicolumn{8}{|c|}{ Mold \&Yeast counts (log CFU /g) } \\
\hline 1 & ND & ND & ND & ND & ND & ND & ND & ND \\
\hline 8 & ND & ND & ND & ND & ND & ND & ND & ND \\
\hline 15 & $1.8^{\mathrm{a}, \mathrm{a}, \mathrm{a}}$ & ND & ND & ND & $1.3^{\mathrm{a}, \mathrm{b}, \mathrm{a}}$ & ND & ND & ND \\
\hline 22 & $2.2^{a, a, a}$ & $1.2^{\mathrm{a}, \mathrm{a}, \mathrm{a}}$ & ND & ND & $1.7^{\mathrm{a}, \mathrm{b}, \mathrm{a}}$ & $1.1^{\mathrm{a}, \mathrm{b}, \mathrm{a}}$ & ND & ND \\
\hline
\end{tabular}

The letters before comma possess the factor of orange level. While those after comma possess the factor of the kind Ricotta cheese and storage period, respectively. The means with the same letter at any position were not significantly different $(P>0.05)$. ND $=$ Not detected

\section{Microbiological quality:}

Coliforms were not detected in all defferant Ricotta cheese treatments either when fresh or during the storage period. This may be due to the high hygienic condition during the preparation and during storage period.

The results of Table (9) indicated that, no significant differences in TBC or Molds and Yeasts counts between kinds of Ricotta cheese whether made from whey or buttermilk. While, significant differences $(P<0.0001)$ were found between the treatments and during storage period. 


\section{Sensory evolution:}

Table 10. Sensory evolution of Ricotta cheeses fortified with different levels of peel and pulp Citrus sinensis when fresh and during storage at $5 \pm 1^{\circ} \mathrm{C}$.

\begin{tabular}{|c|c|c|c|c|c|c|c|c|}
\hline \multirow{4}{*}{$\begin{array}{l}\text { Cold } \\
\text { storage } \\
\text { period } \\
\text { (days) }\end{array}$} & \multicolumn{8}{|c|}{ Treatments } \\
\hline & \multicolumn{4}{|c|}{ Whey ricotta cheese (WRC) } & \multicolumn{4}{|c|}{ Butter milk ricotta cheese (BRC) } \\
\hline & \multicolumn{8}{|c|}{ Levels of supplementing with Citrus sinensis (\%) } \\
\hline & Control & 1 & 3 & 5 & Control & 1 & 3 & 5 \\
\hline & \multicolumn{8}{|c|}{ Appearance (10) } \\
\hline 1 & $10^{\mathrm{b}, \mathrm{a}, \mathrm{a}}$ & $10^{\mathrm{a}, \mathrm{a} \cdot \mathrm{a}}$ & $10^{\mathrm{a}, \mathrm{a}, \mathrm{a}}$ & $7^{c, a, a}$ & $10^{\mathrm{b}, \mathrm{a}, \mathrm{a}}$ & $10^{\mathrm{a}, \mathrm{a}, \mathrm{a}}$ & $10^{\mathrm{a}, \mathrm{a}, \mathrm{a}}$ & $8^{c, a, a}$ \\
\hline 8 & $10^{\mathrm{b}, \mathrm{a} . \mathrm{ab}}$ & $10^{\mathrm{a} . \mathrm{a}, \mathrm{ab}}$ & $10^{\mathrm{a}, \mathrm{a}, \mathrm{ab}}$ & $7^{c, a, a b}$ & $10^{\mathrm{b}, \mathrm{a}, \mathrm{ab}}$ & $10^{\mathrm{a}, \mathrm{a}, \mathrm{ab}}$ & $10^{\mathrm{a}, \mathrm{a}, \mathrm{ab}}$ & $8^{c, a, a b}$ \\
\hline 15 & $7^{\mathrm{b}, \mathrm{a}, \mathrm{a}, \mathrm{ab}}$ & $10^{\mathrm{a}, \mathrm{a}, \mathrm{ab}}$ & $10^{\mathrm{a}, \mathrm{a}, \mathrm{ab}}$ & $7^{c, a, a b}$ & $8^{\mathrm{b}, \mathrm{a}, \mathrm{ab}}$ & $10^{\mathrm{a}, \mathrm{a}, \mathrm{ab}}$ & $10^{\mathrm{a}, \mathrm{a}, \mathrm{ab}}$ & $8^{c, a, a b}$ \\
\hline \multirow[t]{2}{*}{22} & $6^{b, a, c}$ & $7^{b, a, c}$ & $10^{\mathrm{a}, \mathrm{a}, \mathrm{c}}$ & $7^{c, a, c}$ & $7^{b, a, c}$ & $8^{b, a, c}$ & $10^{\mathrm{a}, \mathrm{a}, \mathrm{c}}$ & $8^{c, a, c}$ \\
\hline & \multicolumn{8}{|c|}{ Body and Texture (50) } \\
\hline 1 & $46^{b c, a, a}$ & $48^{\mathrm{ab}, \mathrm{a}, \mathrm{a}}$ & $49^{a, a, a}$ & $38^{c, a, a}$ & $48^{b c, a, a}$ & $49^{\mathrm{ab}, \mathrm{a}, \mathrm{a}}$ & $49^{\mathrm{a}, \mathrm{a}, \mathrm{a}}$ & $40^{c, a, a}$ \\
\hline 8 & $45^{b c, a, a}$ & $48^{\mathrm{ab}, \mathrm{a}, \mathrm{a}}$ & $49^{a, a, a}$ & $38^{c, a, a}$ & $48^{\mathrm{bc}, \mathrm{a}, \mathrm{a}}$ & $49^{a b, a, a}$ & $49^{\mathrm{a}, \mathrm{a}, \mathrm{a}}$ & $40^{c, a, a}$ \\
\hline 15 & $43^{b c, a, a}$ & $48^{\mathrm{ab}, \mathrm{a}, \mathrm{a}}$ & $49^{a, a, a}$ & $38^{c, a, a}$ & $45^{b c, a, a}$ & $49^{a b, a, a}$ & $49^{\mathrm{a}, \mathrm{a}, \mathrm{a}}$ & $40^{c, a, a}$ \\
\hline \multirow[t]{2}{*}{22} & $40^{b c, a, a}$ & $47^{\mathrm{ab}, \mathrm{a}, \mathrm{a}}$ & $49^{a, a, a}$ & $38^{c, a, a}$ & $41^{b c, a, a}$ & $48^{\mathrm{ab}, \mathrm{a}, \mathrm{a}}$ & $49^{\mathrm{a}, \mathrm{a}, \mathrm{a}}$ & $40^{c, a, a}$ \\
\hline & \multicolumn{8}{|c|}{ Flavor (40) } \\
\hline 1 & $40^{\mathrm{a}, \mathrm{a}, \mathrm{a}}$ & $39^{\mathrm{a}, \mathrm{a}, \mathrm{a}}$ & $39^{a, a, a}$ & $30^{\mathrm{b}, \mathrm{a}, \mathrm{a}}$ & $40^{\mathrm{a}, \mathrm{a}, \mathrm{a}}$ & $39^{\mathrm{a}, \mathrm{a}, \mathrm{a}}$ & $39^{\mathrm{a}, \mathrm{a}, \mathrm{a}}$ & $35^{b, a, a}$ \\
\hline 8 & $39^{\mathrm{a}, \mathrm{a}, \mathrm{a}}$ & $39^{\mathrm{a}, \mathrm{a}, \mathrm{a}}$ & $39^{a, a, a}$ & $30^{\mathrm{b}, \mathrm{a}, \mathrm{a}}$ & $40^{\mathrm{a}, \mathrm{a}, \mathrm{a}}$ & $39^{\mathrm{a}, \mathrm{a}, \mathrm{a}}$ & $39^{\mathrm{a}, \mathrm{a}, \mathrm{a}}$ & $35^{b, a, a}$ \\
\hline 15 & $38^{\mathrm{a}, \mathrm{a}, \mathrm{a}}$ & $39^{\mathrm{a}, \mathrm{a}, \mathrm{a}}$ & $39^{a, a, a}$ & $30^{\mathrm{b}, \mathrm{a}, \mathrm{a}}$ & $39^{\mathrm{a}, \mathrm{a}, \mathrm{a}}$ & $39^{\mathrm{a}, \mathrm{a}, \mathrm{a}}$ & $39^{\mathrm{a}, \mathrm{a}, \mathrm{a}}$ & $35^{b, a, a}$ \\
\hline \multirow[t]{2}{*}{22} & $32^{\mathrm{a}, \mathrm{a}, \mathrm{a}}$ & $38^{\mathrm{a}, \mathrm{a}, \mathrm{a}}$ & $39^{a, a, a}$ & $30^{\mathrm{b}, \mathrm{a}, \mathrm{a}}$ & $32^{\mathrm{a}, \mathrm{a}, \mathrm{a}}$ & $38^{\mathrm{a}, \mathrm{a}, \mathrm{a}}$ & $39^{\mathrm{a}, \mathrm{a}, \mathrm{a}}$ & $35^{b, a, a}$ \\
\hline & \multicolumn{8}{|c|}{ Total score $(100)$} \\
\hline 1 & $96^{b, a, a}$ & $97^{\mathrm{a}, \mathrm{a}, \mathrm{a}}$ & $98^{\mathrm{a}, \mathrm{a}, \mathrm{a}}$ & $75^{c, a, a}$ & $98^{\mathrm{b}, \mathrm{a}, \mathrm{a}}$ & $98^{\mathrm{a}, \mathrm{a}, \mathrm{a}}$ & $98^{\mathrm{a}, \mathrm{a}, \mathrm{a}}$ & $83^{c, a, a}$ \\
\hline 8 & $94^{b, a, a}$ & $97^{\mathrm{a}, \mathrm{a}, \mathrm{a}}$ & $98^{\mathrm{a}, \mathrm{a}, \mathrm{a}}$ & $75^{c, a, a}$ & $98^{\mathrm{b}, \mathrm{a}, \mathrm{a}}$ & $98^{\mathrm{a}, \mathrm{a}, \mathrm{a}}$ & $98^{\mathrm{a}, \mathrm{a}, \mathrm{a}}$ & $83^{c, a, a}$ \\
\hline 15 & $88^{b, a, a}$ & $97^{\mathrm{a}, \mathrm{a}, \mathrm{a}}$ & $98^{\mathrm{a}, \mathrm{a}, \mathrm{a}}$ & $75^{c, a, a}$ & $92^{\mathrm{b}, \mathrm{a}, \mathrm{a}}$ & $98^{\mathrm{a}, \mathrm{a}, \mathrm{a}}$ & $98^{\mathrm{a}, \mathrm{a}, \mathrm{a}}$ & $83^{c, a, a}$ \\
\hline 22 & $78^{\mathrm{b}, \mathrm{a}, \mathrm{b}}$ & $92^{\mathrm{a}, \mathrm{a}, \mathrm{b}}$ & $98^{\mathrm{a}, \mathrm{a}, \mathrm{b}}$ & $75^{c, a . b}$ & $80^{\mathrm{b}, \mathrm{a}, \mathrm{b}}$ & $94^{\mathrm{a}, \mathrm{a}, \mathrm{b}}$ & $98^{\mathrm{a}, \mathrm{a}, \mathrm{b}}$ & $83^{c, a, b}$ \\
\hline
\end{tabular}

The letters before comma possess the factor of orange level. While those after comma possess the factor of the kind Ricotta cheese and storage period, respectively. The means with the same letter at any position were not significantly different $(P>0.05)$.

Sensory panel evaluation is an important indicator of potential consumer preferences. As can be seen from Table (10) the results of organoleptic properties revealed that addition of peel and pulp Citrus sinensis had significant effect on flavor, body texture and total score. With regards to the appearance criterion of Ricotta cheese of all treatments, without any exception, were as good as the control whether when fresh or along storage period ( $P>0.05$ ). It could be also noticed that, buttermilk 
Ricotta cheese fortified with peel and pulp Citrus sinensis gained body and texture score significantly higher than those given for whey Ricotta cheese with fortified with

peel and pulp Citrus sinensis or the control. On the other hand, treatment fortified with $5 \%$ peel and pulp Citrus sinensis scored the lowest flavor, body and texture and appearance because the use of high rate from peel and pulp Citrus sinensis (5\%) given rough of body and texture, high orange flavor, also bitter and color orange plus, as antioxidant substances in food products is still limited because of the alteration they promote in flavor, making it necessary to determine the concentrations of it that guarantee the product acceptability. But with prolonging the cold storage period especially after 15 days the sensory evaluation score tended to significant decrease $(P<0.0001)$ in control and $1 \%$ fortified peel and pulp Citrus sinensis treatments.

The sensory total score of Ricotta cheese which reflects the overall organoleptic quality of product reveal that, treatments fortified with $3 \%$ peel and pulp Citrus sinensis led to improve the total sensory quality versus the control or other treatments.In general, Ricotta cheese supplemented with $3 \%$ Citrus sinensis whether made from sweet whey or buttermilk had higher total scores than control cheese.

\section{Cost of ingrediens:}

The calculated cost per $100 \mathrm{~kg}$ of the resultant Ricotta cheese (Table 11) indicated that incorporating Citrus sinensis in the Ricotta cheese with 1, 3 or5 \% lowered the cost by $36.28,61.65$ and $70.19 \%$ respectively, of made buttermilk compared to the cost of control without Citrus sinensis Also, whey Ricotta cheese fortified 3,5\% lowered the cost by $66.7 \%$ and $75 \%$ respectively.

Table 11. Cost of ingredients used in manufacturing Ricotta cheeses fortified with different levels of peel and pulp Citrus sinensis.

\begin{tabular}{|c|c|c|c|c|c|c|c|c|c|}
\hline \multirow{4}{*}{ Ingredients } & \multirow{4}{*}{$\begin{array}{l}\text { Price of } \\
\mathrm{kg} / \mathrm{L.E}\end{array}$} & \multicolumn{8}{|c|}{ Treatments } \\
\hline & & \multicolumn{4}{|c|}{ Whey ricotta cheese (WRC) } & \multicolumn{4}{|c|}{ Butter milk ricotta cheese (BRC) } \\
\hline & & \multicolumn{8}{|c|}{ Levels of supplementing with Citrus sinensi s (\%) } \\
\hline & & Control & 1 & 3 & 5 & Control & 1 & 3 & 5 \\
\hline Sweet whey & - & - & - & - & - & - & - & - & - \\
\hline Sweet butter milk & 2 & - & - & - & - & 763.06 & 285.2 & 291.76 & 226.94 \\
\hline Orange Juce & 3 & - & 3.0 & 2.0 & 1.5 & - & 2.0 & 1.5 & 1.0 \\
\hline Pulp+Peel orange & - & - & - & - & - & - & - & - & - \\
\hline Citric acid & 30 & 6.0 & - & - & - & 1.5 & - & - & - \\
\hline Total cost/ 100 kg & - & 6.0 & 3.0 & 2.00 & 1.5 & 764.65 & 487.2 & 293.26 & 227.94 \\
\hline Cost reduction \% & - & 0.0 & 50 & 66.7 & 75 & 0.0 & 36.28 & 61.65 & 70.19 \\
\hline
\end{tabular}


In conclusion, Rictta cheese can be produced with adding Citrus sinensis up to $3 \%$ in the cheese without any significant difference than that of control without addition.

Impact of Citrus sinensis up to $3 \%$ in the Ricotta cheese produced highly acceptable Ricotta cheese with even improved body \& texture, flavor, appearance, rheological properties, shelf life and economic value. Moreover, the cost was reduced by $61.65 \%, 66.7 \%$ whether made from buttermilk or sweet whey as compared to the traditional manufacturing technique.

\section{REFERENCES}

1. Alsmeyer, R.H.; Gumingham, A. E. and Happich, M. L. 1974. Equation predict PER from Amino acid analysis. Food Technol., 28:134.

2. AOAC 2012. Association of Official Analytical Chemists. $18^{\text {th }}$ Ed. AOAC International Gaithersburg, MD. No. (9685.080), and CH.4,p. 56-57 and no. (985.01), Ch.3, p.6., Official Method of Analysis. (19th Ed.), pp. 9-13.

3. APHA 2004. American Public Health Association.Standard methods of the examination of Dairy products $16^{\text {th }}$ Ed.., APHA .Inc.Washington D. C.

4. Aylward, E. B.; J. Oleary and B. E. Langlois 1980. Effect of milk storage on cottage cheese Yield. J. Dairy Sci., 63: 1819-1825.

5. Benzine I. F. F., and Strain J. J. 1996. The Ferric reducing ability of plasma (FRAP) as a measure of antioxidant power : The FRAP assay. Anal Biochem. 239: 70-76.

6. Ceirwyn S. J. 1995. Analytical Chemistry of Foods. Part Iin book. p. 135.

7. Dewettinck K, Rombaut R, Thienpont N, Le TT, Messens K, Van-Camp J 2008. Nutritional and technological aspects of milk fat globule membrane material. Int Dairy J 18:436-457.

8. FAO/ WHO 1973. Protein and energy requirement, WHOTech. Rep. Ser. No 522, WHO Geneva.

9. FAO/ WHO/ UNU. 1985. Food and Agriculture organization world, Health organization, United Nations University Joint expert consolation energy and protein requirements Geneva. WHO Technical report series 724.

10. Fernandez-Lopez, J., Gines, M. J., Carbonell- Aleson, L., Sendra, E., BarberaSayas, E. and Perez- Alvarez, A. J. 2004. Application of functional citrus byproduct to meat products. Trends Food Sci. Technol., 15: 176. 
11. Fernandez-Lopez, J., N. Zhi, L. Aleson-Carbonell, J.A. Perez- Alvarez and V. Kuri. 2005. Antioxidant and antibacterial activities of natural extracts: application in beef meatballs. Meat Sci.. 69: 371-380.

12. Forsum, E. 1974. Nutritional evaluation of whey protein concentrates and their fractions. J. Dairy Sci. 57, 6: 665-670.

13. Fox, F.; Guinee, P.; Cogan M. and Mc Sweeney, H. 2000. Fundamentals of cheese science. MD: Aspen Publ. Gaithersburg.

14. Hegazy A. E. and Ibrahium M. I. 2012. Antioxidant Activities of Orange Peel Extracts. World Applied Sciences Journal, 18 (5): 684-688.

15. IDF, 1990. Milk and Milk produces Enumeration of Yeasts and Moulds Colony Count at $25^{\circ} \mathrm{C}$. Standard 94B. Brussels: International Dairy Federation.

16. Lollo, P. C. B., Silva, L. B. C., Batista, T. M. et al. 2012. Effects of whey protein and casein plus leucine on diaphragm the mTOR pathway of sedentary, trained rats. Food Research International, 49, 416-424.

17. Mahran G. A., Hammad Y. A., Ahmed N. S., Sayed AF. And Abd-EI-Aziz M. 1999. Manufacture of ricotta cheese from whey fortified with skim milk powder using different acidulants. Egyptian Journal of Dairy Science 27: 191-203.

18. Mamta, A. and Parminder, K. 2013. Antimicrobial and Antioxidant Activity of Orange Pulp and Peel.International Journal of Science and Research (IJSR).Volume 2 Issue 11, November 2013.

19. Mitchell, H. H. and Block, R. J. 1946. Methods for for evaluation of nutritional adequacy and States. Nutrition Abst. 8 Res., 16: 249.

20. McIntosch, G. H.; Royle, P. J.; Leleu, R. K.; Regester, G. O.; Johnson, M. A.; Grinsted, R. L.; Kenward, R. S. and Smithers, G. W. 1998. Whey proteins as functional food ingredients. International Dairy Journal, 8:425.

21. Nelson, A. L. (2001).High-Fiber Ingredients. St. Paul, MN: Eagan.

22. Pizzillo, M.; Claps, S.; Cifunj, G. F.; Fedele, V. and Rubion, R. 2005. Effect of goat breed on the sensory, chemical and nutritional characteristics of Ricotta cheese Liverstock Production Science94: 33-40.

23. Pintado, M. E. and F. X. Malcata. 2001. Characterization of whey cheese packaged under vacuum. J. Food Prot. 63, (2): 216- 221.

24. Rodney, J. B. and Ernstrom, C. A. 1982. Incorporation of UF. Concentrate whey solids into Chedder cheese for increased yield. J. Dairy Sci. , 65 (12): 2391-2395.

25. SAS, 1996. Statistical Analysis System.SAS users guide Statistics. SAS Inst. Inc. Ed., Cary, NC, U.S.A. 
26. Saénz C, Estevéz A, Sanhueza S. Utilización. 2007. de los residuos de la industria de jugos de naranja como fuente de fibra dietética en la elaboración de alimentos. Arch Latin Nutr 57:186-191. Cited from Maria R. Romero-Lopez 1, Perla Osorio-Diaz, Luis A. Bello-Perez, Juscelino Tovar and Aurea BernardinoNicanor 2011. Fiber Concentrate from Orange (Citrus sinensis..) Bagase: Characterization and Application as Bakery Product Ingredient. Int. J. Mol. Sci. $2011,12,2174-2186$.

27. Turcot S., Turgeon SL, St-Gelais D. 2001. Effect of buttermilk phospholipid concentrations in cheese milk on production and composition of low-fat Cheddar cheese. Dairy Sci Technol 81:429-442. 
تأثير إستخدام البرتقال على الصفات الطبيعية والكيماوية لجبن الريكوتا

$$
\text { أمل إبر اهيم الارديرى }
$$

$$
\text { قسم كبياء الألبان - معهد بحوث الإنتاج الحبوانى- مركز البحوث الزراعية-الجيزة- مصر }
$$

تعتبر الجبن الريكوتا المصنعة من شرش الجبن أو من اللبن الخض الحلو والمدعمة بالبرتقال البلاى غذاء لبنى وظيفى عالى فى مضادات الأكسدة و مدة الحفظ. فقد تم تدعيم الجبن

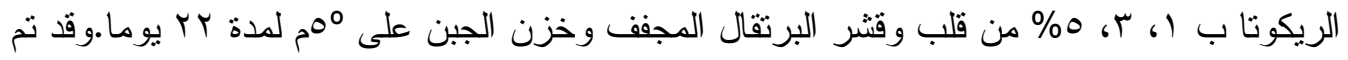
تحليل معاملات الجبن المختلفة و تقدير نشاط مضادات الاكسدة واجرى عليها الاختبار ات الكيماوية

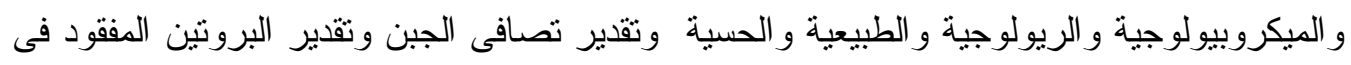

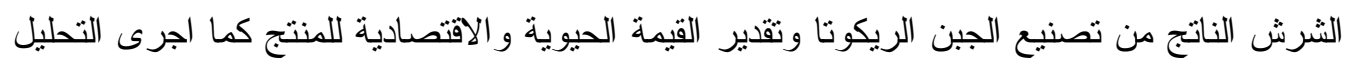

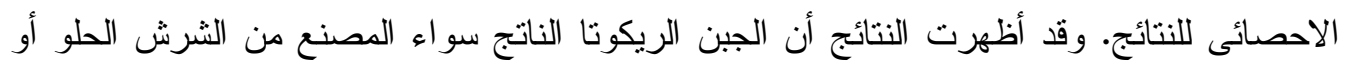

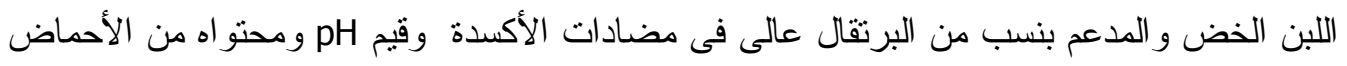
الأمينية الأساسية والغير أساسية و التصافى و التحكيم الحسى مع إنخفاض فى قين فيم الأعداد البكتيرية،

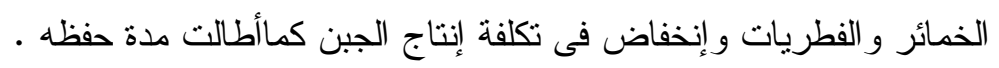

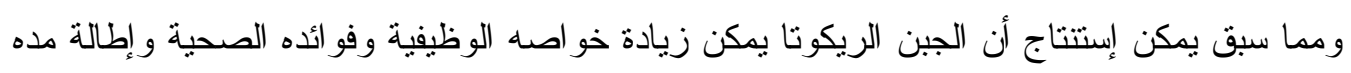

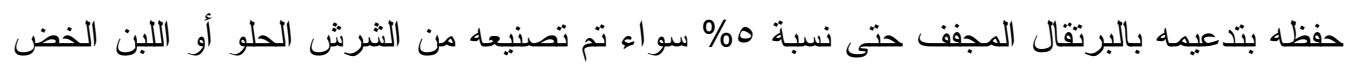

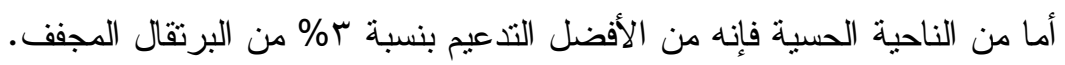

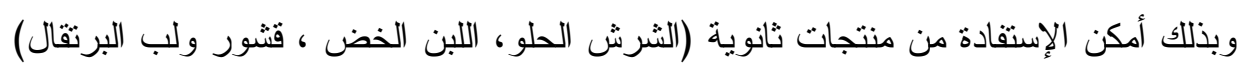
فى صناعة جبن وظيفى عالى فى جميع الخواص والحد من التلوث البيئى الناتج من وجود هذه الإنه المنتجات الثانوية. 